\title{
ONLINE MUSIC JOINT VENTURES: TAKEN FOR A SONG
}

\author{
Harry First ${ }^{*}$
}

\begin{abstract}
In 2001 the five major record companies, controlling more than 80 percent of prerecorded music sales in the United States, announced the formation of two joint ventures to distribute music over the Internet. The Department of Justice opened an antitrust investigation into these ventures even before the ventures began their operations. Two and one-half years later the Department announced that it had closed the investigation because its theoretical concerns ultimately were not supported by the evidence. The Department s investigation, however, focused on the ventures licensing practices rather than on their formation.

This article focuses on the formation of the online music joint ventures. The article begins with a description of the business and legal environment in which the joint ventures were formed and traces developments in both since the ventures formation. Included in this description is the effort by the industry to suppress widespread copyright infringement and the entry of a number of new companies into the online music market. The article $s$ antitrust analysis examines the predicted anticompetitive effects of the formation of the ventures and, drawing on the Supreme Court s decision in Broadcast Music, Inc. v. Columbia Broadcasting System, Inc. and the history of performing rights organizations, argues that the efficiency justifications for the online music joint ventures were quite modest. The article concludes that the formation of the ventures was anticompetitive, without regard to the ventures licensing practices, and that the appropriate remedy would have been either to unwind the two ventures or divest the record companies ownership of them. Although the online music industry did not develop as might have been predicted when the ventures were formed, we owe these positive developments to the inability of the music industry to control the widespread infringement of their copyrights. Had the record industry s campaign been successful, the competitive structure in the online music market would likely have been quite different and the proposed antitrust remedies would have been necessary to bring competition to the market for online music.
\end{abstract}

\footnotetext{
*Professor of Law, New York University School of Law. I thank Peter Carstensen, Edward Cavanagh, Rochelle Dreyfuss, Rebecca Tushnet, and Diane Zimmerman, as well the participants at the Third Annual Loyola (Chicago) Antitrust Colloquium, for their very helpful comments on earlier drafts. I also thank Lee Bollinger, Idit Froim, and Daniel Hemli for their very valuable research assistance. This research was supported by the generosity of the Filomen and Max D Agostino Research Fund at New York University. 2004 Harry First.
} 
Online Music Joint Ventures: Taken For A Song

Table of Contents

I. Introduction

II. The Online Music Business

A. Prerecorded Music Distribution

B. The Legal Environment

1. Copyright protection

2. File sharing

C. Online Music Ventures

III. Antitrust Analysis of Online Music Joint Ventures

A. Market Definition

B. Competitive Effects of Joint Ventures

C. Forming the Joint Ventures

1. BMI's guidance

2. Fragmented rights and the need for pooling

3. Demand-side economies and one-stop shopping

4. Applying $B M I$

5. Remedy

IV. Conclusion

\section{Introduction}

Perhaps no industry has been more fundamentally challenged by the growth of the Internet and its related technologies than the recorded music industry. For most industries, the Internet mainly provides a new, albeit potentially far more efficient, channel of distribution. For the recording industry, however, the Internet has challenged the basic product the industry makes and the way it does business. The recording industry has mostly bundled prerecorded music into packages ( albums ); the Internet offers consumers the opportunity to unbundle music and choose only the songs they want to hear. The recording industry has maintained tight control over which artists get to distribute their work to the public; the Internet offers the opportunity for artists to deliver music directly to consumers. The recording industry has created the end-product on which songs are sold (music on CDs, tape, and vinyl records); computer software and hardware allows consumers to capture recorded music on the media of their choice. The recording industry has owned the copyrights to the music they sell; computer software and Internet connections allow consumers 
to obtain music for free, in seeming disregard for copyright protection and the economic interests of the copyright holders.

The initial response of the recording industry to some of the challenges posed by the Internet was the creation of two joint ventures, pressplay and MusicNet, to distribute music online. Producer joint ventures to control Internet distribution are not unique to the recording industry (the airline, hotel, and motion picture industries have also started such ventures), but the recording industry joint ventures dealt with some particularly challenging issues of antitrust, copyright, and innovation policy. When the online music joint ventures were announced, they appeared to offer more competition and significant efficiency benefits, creating new entrants with a new product in a new market. Given the concentrated nature of the prerecorded music industry, however, and the ability of the record companies to control the licensing of their music to online music distributors, it was also clear that the joint ventures deserved closer antitrust scrutiny. Indeed, the Department of Justice and the European Commission opened investigations of the two ventures even before the ventures began their operations.

Two and one-half years later the Department of Justice announced that it had closed its investigation because its theoretical concerns ultimately were not supported by the evidence. ${ }^{1}$ However appropriate this decision might be as a matter of enforcement policy, however, the Department s explanation focused only on the ventures licensing practices and sheds little light on the appropriate analysis of the ventures formation.

The thesis of this article is that the formation of these producer joint ventures was not justified by any efficiencies and that their formation was anticompetitive. More broadly, this article argues that the brief history of this industry demonstrates the danger to competition posed when the producers of essential inputs in a concentrated market join together to control downstream distribution, a danger exacerbated in this industry, involving, as it does, the distribution of intellectual property products.

The article begins with a description of the business and legal environment in which the joint ventures were formed and then traces how both have developed since the ventures formation. The article then provides an analysis of whether the formation of the two joint ventures violated Section 1 of the Sherman Act. The article concludes with some observations regarding record industry joint ventures in today $\mathrm{s}$ rapidly changing market for the distribution of online music.

\section{The Online Music Business}

\footnotetext{
${ }^{1}$ Department of Justice Antitrust Division, Statement Regarding the Closing of its Investigation into The Major Record Labels pressplay and MusicNet Joint Ventures at 4 (issued December 23 , 2003), http://www.usdoj.gov/atr/public/press_releases/2003/201946.htm. available
} 
Online Music Joint Ventures: Taken For A Song

\section{A. Prerecorded Music Distribution}

Sales of prerecorded music are substantial. Over the decade 1993-2002, the value of prerecorded music sales in the United States ranged between $\$ 10$ billion and $\$ 14.5$ billion annually. ${ }^{2}$ Sales generally increased each year during that period, until 2001. ${ }^{3}$ Although sales declined in 2001 and again in 2002, sales in 2002 were still higher than they were in every year from 1993 through 1998 and the decline may be reversing. ${ }^{4}$ The cause of the sales decline, however, is the subject of some controversy. ${ }^{5}$

There are five major companies (often referred to as distributors ) that manufacture prerecorded music produced by labels that they own. These five companies accounted for approximately 83 percent of U.S. album sales in 2002 (as they did in 2001). ${ }^{6}$ The five companies are Universal Music Group ( UMG ), with $28.9 \%$ of sales in $2002,{ }^{7}$ Warner-Elektra-Atlantic Corporation, with $15.9 \%,{ }^{8}$ Sony Music Entertainment, with $15.7 \%,{ }^{9}$ BMG Music, with

\footnotetext{
${ }^{2}$ See The Recording Industry Ass $\mathrm{n}$ of America, 2002 Yearend Statistics, available at http://www.riaa.com/news/marketingdata/pdf/year_end_2002.pdf (total dollar value of all shipments, net of returns; includes CDs, cassettes, LPs, music videos, and DVD video and audio; bulk of revenue is in CD sales). By comparison, in 2002 U.S. movie box office gross revenues were $\$ 9.5$ billion and U.S. video game industry had $\$ 10.3$ billion in retail sales. See U.S. Entertainment Industry: 2002 MPA Market Statistics, an economic review by the Motion Picture Association, available http://www.mpaa.org/useconomicreview/2002/2002_Economic_Review.pdf, and The NPD Group Reports Annual 2002 U.S. Video Game Sales Break Record, January 27, 2003, available at http://www.npd.com/press/releases/press_030128a.htm.

${ }^{3}$ There was a 2.5 percent drop in revenues between 1996 and 1997. Id.

${ }^{4}$ See Ethan Smith, Music Industry Sounds Upbeat as Losses Slow, WALL ST. J., Jan. 2, 2004, at B1 (including sales by online services, 2003 sales only .8\% less than 2002 sales; excluding online sales, sales in 2003 were $2.1 \%$ less than 2002).

${ }^{5}$ See, e.g., Declining Music Sales: It's Not All Digital Downloading, Says The NPD Group, June 5, 2003, available at http://www.npd.com/press/releases/press_030605.htm (based on consumer surveys, half of lost sales attributed to free file sharing; but $\overline{6} 0$ percent of music consumers with Internet access have not downloaded any music and sales to these consumers have also dropped; half of consumers aged 36 and over report that there is less music that they are interested in buying); Music Industry Sounds Upbeat, supra note 4 (strong sales in fourth quarter of 2003 included a number of hit albums, such as OutKast s Speakerboxxx/The Love Below and Norah Jones Come Away With Me ).

${ }^{6}$ See Ed Christman, UMVD expands market-share dominance, BILLBOARD, January 18, 2003 (based on SoundScan data). The market share of the top five distributors was 83 percent in 2001 as well, see Ed Christman, UMVD marks 3rd straight year as top U.S. music distributor: UMVD leads in total, current album share, BILLBOARD, Jan. 26, 2002.
}

${ }^{7}$ UMG s labels include A\&M, Def Jam, Geffen, Island, MCA, Motown, Polydor, Universal and Verve.

${ }^{8}$ Warner s labels include Warner Brothers Records Inc., Atlantic Recording 4 
$14.8 \%,{ }^{10}$ and EMI Music Distribution, with $8.4 \%{ }^{11}$ Warner was traditionally the market leader until UMG s 1998 acquisition of Polygram, which had been the sixth major distributor; UMG has led the market every year since that acquisition. At the time the joint ventures were announced, four of the five major distributors were owned by larger companies, each with substantial media and entertainment interests (respectively, Vivendi, AOL/Time-Warner, Sony, and Bertelsmann), but the industry s ownership structure has not been stable. In 2000 Warner and EMI had attempted to merge their music businesses, but abandoned the effort after antitrust opposition from the European Commission. ${ }^{12}$ In November 2003 Bertelsmann and Sony announced a merger of their music companies and Warner announced the sale of its music business to a group of private investors (rejecting a higher offer from EMI and after failing to reach a merger agreement with BMG). ${ }^{13}$ Under the U.S. Department of Justice/Federal Trade Commission Merger Guidelines, the industry would have been viewed as moderately to highly concentrated when the joint ventures were announced. ${ }^{14}$

The five major distributors are vertically integrated through manufacturing and wholesaling. Through their labels these companies contract with recording artists to record music. The labels oversee production of the recording and develop promotional plans; the distribution companies handle wholesale distribution and engage in various, often extensive, promotional efforts. These promotional efforts include securing television appearances for the artists, radio play for the music, and the payment of (sometimes extensive) fees to retail outlets to promote the records.

Corporation, Rhino Entertainment Company and Elektra Entertainment Group, Inc.

${ }^{9}$ Sony s labels include Columbia, Epic, WORK Group, C2, Nashville, Sony Classical, and Sony Wonder.

\section{Entertainment.}

${ }^{10} \mathrm{BMG}$ s labels include RCA, Arista, BMG Classics, Windham Hill and Bad Boy

${ }^{11}$ EMI s labels include Capitol, Capitol Nashville, Blue Note, Angel Records and EMI Latin.

${ }^{12}$ See Regulators Sink EMI-Time Warner Deal, WaLl ST. J., Oct. 6, 2000.

${ }^{13}$ See Mark Lander, Bertelsmann and Sony to Join Music Units, N.Y. Times, Nov. 7, 2003, at C1; Ethan Smith \& Charles Goldsmith, Bronfman Group Wins Warner Music, WALL ST. J., Nov. 25, 2003, at B4.

${ }^{14}$ If the independents are considered as a single firm, the Herfindahl-Hirschman Index (HHI) is 1893; otherwise the HHI would be slightly over 1600. The federal enforcement agency Guidelines consider a market with an HHI above 1800 as highly concentrated ; markets between 1000 and 1800 are considered moderately concentrated. See United States Department of Justice and Federal Trade Commission, HoRIZONTAL MERGER GUIDELINES 1.5. If the Bertelsmann-Sony merger is completed without challenge, the HHI would increase by more than 400 points, making the market highly concentrated. 
Retail distribution is done through a variety of channels. The three main channels are traditional retailers that specialize in the sale of prerecorded music (such as Tower Records), general merchandise discount retailers that do not specialize (such as Wal-Mart), and electronics discounters (such as Best Buy). Retail distribution is also done through record clubs, which distribute their records by mail order; some of the major distributors have ownership interests in these clubs (for example, Columbia House, the largest club, is jointly owned by Sony and Time-Warner). Retailers generally sell all or most genres of prerecorded music and do not limit their sales to music sold by any one particular distributor or recorded on any particular label.

The growth and spread of the Internet has expanded retail distribution channels. Internet distribution offers some obvious efficiencies in comparison with traditional brick and mortar retail distribution (centralized inventorying, no retail stores, fewer personnel). The first step in taking advantage of these efficiencies came when new retailers, such as Amazon and CDnow, began selling prerecorded music on the Internet; this led traditional music retailers (such as Tower) to start their own Internet sales sites. These Internet sites, however, still sold the same product that is sold through physical stores, which then needed to be physically delivered to consumers by mail.

The Internet, however, provides the opportunity to distribute prerecorded music in a form that is substantially different from music sold in physical stores, or even through Internet retail sites. ${ }^{15}$ Prerecorded music in digital format can readily be transmitted via the Internet (and subsequently listened to, stored, and replayed) divorced from the physical medium in which it was originally embodied. Freed from the need for distribution of the original physical medium, the original prerecorded package can also be untied and the music distributed in different combinations (most obviously, by single songs). The channels for this type of prerecorded music distribution bear more resemblance to applications program software than they do to physical stores (these channels relying, for example, on critical software technologies for file compression and transmission). These new distribution channels can be thought of as distribution platforms, to distinguish them from physical stores and Internet sales sites.

\section{B. The Legal Environment}

\section{Copyright protection}

Prerecorded music is protected by copyright. Copyright law provides protection to the underlying musical work (the song) and to the sound

\footnotetext{
${ }^{15}$ See generally Randal C. Picker, Copyright as Entry Policy: The Case of Digital Distribution, 47 ANTITRUST Bull. 423, 429 (2002) (discussing changes caused by online distribution).
} 
recording (the sound of the song). ${ }^{16}$ Different parties generally own different rights; music publishers and/or songwriters generally control the musical works while the record companies or the recording artists generally control the sound recording right. ${ }^{17}$

The owner of the copyright in the musical work has the right to control its public performance, distribution, and reproduction. ${ }^{18}$ Absent the copyright owner s permission, a song cannot be performed in public (for example, by broadcasting it over the radio). Once the song is recorded, however, the reproduction and distribution rights are subject to a statutory compulsory license (the mechanical license ) which permits other performers to reproduce and distribute the song on payment of a prescribed fee. ${ }^{19}$

The owner of the copyright in the sound recording has only a reproduction and distribution rights, but not a performance right. ${ }^{20}$ That is, the copyright holder can prevent others from reproducing and distributing the particular recording of a song, but cannot prevent others from publicly performing the recording (say, by broadcasting it over the radio).

Internet transmission of music in digital formats potentially involves both the public performance and the reproduction of the copyrighted works. Congress has altered the general copyright statute, however, to take account of what it believed were the special problems raised by digital distribution.

For musical works, Congress in 1995 extended the compulsory mechanical license to include the digital distribution of musical works by digital phonorecord delivery ( DPD ). ${ }^{21}$ Under this provision, the Internet transmission of a song that is downloaded to a computer creates a DPD, thereby requiring the payment of a compulsory license fee. ${ }^{22}$ The performance right for

\footnotetext{
${ }^{16}$ See 17 U.S.C. 101 (sound recording is a work that results from the fixation of a series of musical, spoken, or other sounds which can be embodied in material objects such as disks, tapes, or other phonorecords ).

${ }^{17}$ See http://www.riaa.com/issues/licensing/howto.asp.

${ }^{18}$ See 17 U.S.C. $106(1),(3),(4)$.

${ }^{19}$ See 17 U.S.C. 115 . The Harry Fox Agency is the licensing agent for the copyright owners of most musical works (but not all), the copyrights to which are generally owned by music publishing companies, and most performers take mechanical licenses from the Harry Fox Agency rather than from the Copyright Office. See R. Anthony Reese, Copyright and Internet Music Transmissions: Existing Law, Major Controversies, Possible Solutions, 55 U. Miami L. REV. 237, 243 and n. 18 (2001).

${ }^{20}$ See 17 U.S.C. 114 (a).

${ }^{21}$ Digital Performance Right in Sound Recordings Act, Public Law 104-39.

${ }^{22}$ See Reese, supra note 19 , at 243-44. There is some question whether the DPD right applies to the retention in RAM of portions of a song transmitted over the Internet (which is typical of streaming software which buffers the transmission to allow for continuous reception). See id. at 253-54.
} 
musical works, however, was unaffected by the 1995 statute. Internet transmission of music to the public, even when received by someone who is listening at home, is a public performance for which permission is needed from the owner of the copyright in the musical work. ${ }^{23}$

The 1995 statute also created a new public performance right for sound recordings that are performed by a digital audio transmission. ${ }^{24}$ The new performance right distinguishes between interactive and noninteractive transmission services. Interactive services allow recipients to choose the music they want to hear; noninteractive services more closely resemble radio broadcasting, where the transmitter chooses the music that is transmitted. ${ }^{25}$ For certain noninteractive transmission services the statute provides for a compulsory license (with fees to be set by the Librarian of Congress). ${ }^{26}$ For interactive transmission services, however, permission of the owner of the copyright in the sound recording is required.

The sound recording reproduction and distribution rights are unchanged in the digital environment. Permission of the owner of the copyright in the sound recording is still required for making and distributing copies of sound recordings that are transmitted digitally.

\section{File sharing}

A rather remarkable convergence of complementary technologies and products has led to a situation where music listeners can share and copy substantial amounts of prerecorded music without paying royalties to any of the owners of the copyrights in the music or the sound recordings. These technologies include the growth of the Internet itself, the development of faster modems and broadband connections to the Internet, the increased dispersion of personal computers with ever-increasing disk storage space, and the development and dispersion of CD-ROM drives and software that enable users to copy ( burn ) digital files to CDs.

\footnotetext{
${ }^{23}$ See id. at 245-46. ASCAP and BMI contend that transmission for downloading also constitutes a public performance, even if the music is not audible during the transmission but only after the download. See id. at 260.

${ }^{24} 17$ USC 106 (6). The Digital Performance Right in Sound Recordings Act (DPRA) was subsequently amended in 1998 by the Digital Millennium Copyright Act (DMCA).

${ }^{25}$ See 17 USC 114 (j) (defining an interactive service as one that enables a member of the public to receive a transmission of a program specially created for the recipient, or on request, a transmission of a particular sound recording, whether or not as part of a program, which is selected by or on behalf of the recipient ).

${ }^{26}$ The statute places further restrictions on what webcasters operating under the compulsory license can do, including restrictions on the selections of sound recordings being transmitted (the sound recording complement ) and on the type of programming information provided. See 17 USC $114(\mathrm{~d})(2)(\mathrm{C})$.
} 
Particularly critical to the growth of free sharing of prerecorded music has been the development of file compression technology and of software enabling users to share these files. File compression technology began in 1987 when the Moving Picture Experts Group set a standard file format for the storage of audio recordings in a digital format called MPEG-1 layer 3, abbreviated as "MP3." ${ }^{27}$ Compressing songs into smaller files first enabled users to rip songs from CDs and then allowed them to transmit those files over the Internet much more quickly, either by email or other file transfer protocol. ${ }^{28}$

Software enabling users to share files easily emerged in 1999 when Shawn Fanning developed the MusicShare software which was offered on the Napster website. This software enabled a user: (1) to list MP3 files stored on the user s computer hard drive that the user was willing to make available to other Napster users for copying; (2) to search for MP3 music files stored on other users' computers; and (3) to connect with a host user and download a copy of the contents of an MP3 file from one computer to the other over the Internet, "peerto-peer." 29 Napster proved extremely popular, eventually attracting an estimated 50 million users.

Copyright holders sued Napster in 1999 for contributory and vicarious copyright infringement, successfully concluding the litigation in 2002 and shutting Napster down. ${ }^{30}$ Despite the Court of Appeals complete rejection of a variety of copyright defenses asserted by Napster, and the uncontested nature of the infringement of the reproduction and distribution rights by users of Napster, and, indeed, the demise of Napster, file sharing services continued to operate and copyright holders continued to litigate against them. ${ }^{31}$

${ }^{27}$ See A\&M Records, Inc. v. Napster, Inc., 239 F.3d 1004, 1011 (9th Cir. 2001); Matthew Fagin, Frank Pasquale, and Kim Weatherall, Beyond Napster: Using Antitrust Law to Advance and Enhance Online Music Distribution, 8 B.U. J. SCI. \& TECH. L. 451, 458 n.10 (2002). MP3 is not the only file compression technology, but it is apparently the most popular.

${ }^{28}$ For example, a three-minute song of 32 megabyte size could be compressed into an MP3 file of about three megabytes. Id.

${ }^{29}$ A\&M Records, 239 F.3d at 1012.

${ }^{30}$ See A\&M Records, Inc. v. Napster, Inc., 239 F.3d 1004 (9th Cir. 2001) (affirming grant of preliminary injunction against Napster for contributory copyright infringement), 284 F.3d 1091 (9th Cir. 2002) (upholding order to shut down service). See also UMG Recordings, Inc. v. MP3.com, Inc., 92 F. Supp. 2d 349 (S.D.N.Y. 2000) (defendant s service, allowing consumer-owners of CDs to access via the Internet copies of musical compositions recorded on those CDs, violated copyright laws where the actual stored and transmitted copies were made by defendant without authorization from copyright owners).

${ }^{31}$ Litigation is also proceeding against services that enable users to search for music files. See, e.g., Arista Records Inc. v. MP3Board Inc., 2002 U.S. Dist. LEXIS 16165 (S.D.N.Y. 2002) (suit seeking to enjoin operation of Web site that permits users to search the Internet for MP3 files; denying motions for summary judgment). The Napster brand was subsequently resuscitated by a new venture that acquired the assets of pressplay. See infra text accompanying note 58 . 
The most popular file sharing software currently in use is KaZaA. $\mathrm{KaZaA}$ is based on FastTrack software, which, unlike Napster, does not create a centralized database that a single firm monitors or controls. ${ }^{32}$ KaZaA s usage has now far surpassed Napster at its peak. ${ }^{33}$ Between its creation in April 2000 until September 2003, for example, nearly 280 million copies had been downloaded, with approximately 2.5 million new downloads a week. ${ }^{34}$ Only somewhat less popular have been file sharing software programs based on Gnutella, an open-source peer-to-peer platform that is even less centralized than the FastTrack network. ${ }^{35}$ By September 2003 nearly 125 million copies of the two main file sharing platforms using Gnutella (Morpheus and LimeWire) had been downloaded. ${ }^{36}$

Copyright litigation against these file sharing platforms has not been as successful as the litigation against Napster. Sued by both the music and motion picture industries, file sharing software companies that offer software based on FastTrack and Gnutella have so far been successful in asserting that their decentralized design frees them from contributory or vicarious copyright infringement, the grounds relied on by the Ninth Circuit in finding that Napster violated the copyright laws. ${ }^{37}$

The inability to shut down the distributors of file sharing software has led the industry to focus directly on the consumers who actually engage in downloading and uploading copyrighted music. Beginning at the end of 2002, the industry first sought names from Internet service providers of heavy music

\footnotetext{
${ }^{32}$ For a description of the software. see Metro-Goldwyn-Mayer Studios, Inc. v. Grokster, Ltd., 259 F.Supp. 2 d 1029 (C.D. Cal. 2003); Fagin et al., supra note 27, at 461.

${ }^{33}$ See Amy Harmon, Music Industry In Global Fight On Web Copies, N. Y. TIMES, Oct. 7, 2002, at A1, A6 (nearly 3 million users of KaZaA Media Desktop software at any given time, roughly double Napster $\mathrm{s}$ usage at its peak).

${ }^{34}$ See http://download.com.com/3101-2001-0-1.html?tag=pop, visited October 3, 2003 (data compiled by CNET). For earlier figures, see, e.g., Rob Fixmer, Showtime, Microsoft Style, N.Y. TIMES, Sept. 26, 2002, at G1 (reporting 2.7 million downloads for the week of September 15, 2002). By the summer of 2003 the number of downloads of KaZaA was five times the number of downloads of Napster. See Kevin J. Delaney, KaZaA Founder Peddles Software to Speed File Sharing, WALL ST. J., Sept. 8, 2003, at B1. Not all downloads are for new users; some of these downloads are duplicates and upgrades. See Sandeep Junnarkar, Honest Thief Confronts Music Industry, CNET News.com, http://news.com.com/2100-1023-985484.html.
}

\footnotetext{
${ }^{35}$ For a description of the Gnutella technology, see Grokster, 259 F.Supp.2d at 1041 (users are connected through publicly available directories).

${ }^{36}$ See download.com, supra note 34 .

${ }^{37}$ See Grokster, 259 F. Supp. 2 d at 1043 (defendants are not significantly different from companies that sell home video recorders or copy machines, both of which can be and are used to infringe copyrights ) (granting defendant software companies motions for summary judgment relating to contributory and vicarious copyright liability) .
} 
sharers. ${ }^{38}$ The industry then filed suits against four students who ran file-sharing systems at three universities. ${ }^{39}$ Four months after the settlement of those suits, the industry filed copyright infringement suits against 261 individuals across the country who allegedly had more than 1,000 songs each on their personal computers. $^{40}$ This litigation approach has proved to be controversial, and its deterrent effects are as yet unknown, but the industry has continued its effort to sue individual consumers who share substantial amounts of music. ${ }^{41}$

\section{Online Music Ventures}

There are three somewhat different platforms for the distribution of music on the Internet: file-sharing services, webcasters, and interactive music services. File-sharing services provide downloading and burning; noninteractive services ( webcasters or Internet radio ) transmit a stream of music to consumers via the Internet, allowing consumers to choose from an array of music formats that is much larger than is available on over-the-air radio but which cannot be downloaded and replayed; interactive music services offer varying combinations of streams of music, downloading, and burning.

The recording industry $\mathrm{s}$ initial efforts to enter the online music business came in December 2001 in the form of two joint ventures, pressplay and

\footnotetext{
${ }^{38}$ The industry $\mathrm{s}$ initial efforts to use the provisions of the Digital Millennium Copyright Act to obtain from Internet service providers the names of alleged infringers was rejected in Recording Indus. Ass $\mathrm{n}$ of Am., Inc. v. Verizon Internet Services, Inc., 2003 U.S. App. LEXIS 25735 (D.C. Cir. 2003). For reaction to the initial effort to obtain names of alleged infringers, see Dennis K. Berman \& Anna Wilde Mathews, Is the Record Industry About to Bust Your Teenager?, WALL ST. J., Jan. 28, 2003, at D1.

${ }^{39}$ See Amy Harmon, Recording Industry Goes After Students Over Music Sharing, N.Y. TimES, April 23, 2003, at A1.

${ }^{40}$ See Amy Harmon, Suit Settled for Students Downloading Music Online, N.Y. TIMES, May 2, 2003, at A22 (settlements ranged between $\$ 12,000$ and $\$ 17,000$ each; billions of dollars originally asked for in relief; I don t believe I did anything wrong, said one of the students). Nick Wingfield \& Ethan Smith, The High Cost of Sharing, WALL ST. J., Sept. 9, 2003, at B1 (70 suits filed in New York).

${ }^{41}$ For an argument that file sharing can be deterred by a risk of jail or a fine, see Josh Bernoff, Can Young File Sharers Be Stopped? Yes!, available at http://www.forrester.com/ER/Research/Brief/0,1317,17183,00.html\#fig_1 (61\% to 74\% of downloaders between 12 and 22 would stop downloading; approximately $30 \%$ would stop if it took twice as long to download); Ethan Smith, Music Industry Sounds Upbeat as Losses Slow, WALL ST. J., Jan. 2, 2004, at B1 (reporting increased sales of music for 12 of 16 weeks after suits were filed; also reports that a series of hit albums were released during that period). See also John Schwartz, Music Industry Returns to Court, Altering Tactics of File Sharing, N.Y. TIMES, Jan. 22, 2004, at C1 (filing suit against 532 alleged large-scale individual infringers); Saul Hansell, Crackdown on Copyright Abuse May Send Music Traders Into Software Underground, N.Y. TiMES, Sept. 9, 2003, at C1 (discussing growth of software that masks users so that record industry cannot locate infringers).
} 
MusicNet, which were interactive subscription services that provided online music for a monthly fee. ${ }^{42}$ Pressplay was owned by UMG and Sony, the first and third largest sellers of prerecorded music in physical form, with approximately 42 percent of that market. MusicNet was approximately 60 percent-owned by Warner, BMG, and EMI, the second, fourth, and fifth largest sellers of prerecorded music in physical form, with approximately 41 percent of that market. ${ }^{43}$ RealNetworks, a developer of media playing software and an Internet content distributor, owned approximately 40 percent of the MusicNet venture. ${ }^{44}$

Each of the two joint ventures, as originally structured, held licenses for music only from its parent companies. ${ }^{45}$ This meant that consumers who wanted access to all the music controlled by the five largest distributors would need to subscribe to both services. The two ventures also differed in the services they offered. Both restricted the number of songs that could be streamed, but with different amounts. Both services offered tethered downloads (downloads of songs that expired once the subscription was ended or had other types of restrictions that prevented sharing), but of different numbers of songs. Only pressplay offered burning of songs to CDs (at an additional cost). ${ }^{46}$ Both services charged the same monthly fee (\$9.95).

Consumer reaction to the original offerings was tepid, with the two ventures reportedly having only 100,000 subscribers combined by mid-2002. ${ }^{47}$ In fact, AOL, a part-owner of MusicNet, did not even distribute MusicNet when it was originally launched, apparently because the service was so poorly received. ${ }^{48}$

\footnotetext{
${ }^{42}$ Vivendi, the parent of UMG, had two pre-existing separate online ventures. One is EMusic, an MP3 subscription service acquired in 2001, which subsequently offered some UMG back catalogue for downloading. See Jefferson Graham, Pay-for-play music services mimic Napster, The Journal News, Aug. 12, 2002, at 4D. The other is MP3.com.

${ }^{43}$ In 2003 Sony acquired a 4\% stake in MusicNet in the form of a convertible note. See Reuters, Sony backs rival MusicNet, CNET News.com, February 27, 2003 available at, http://news.com.com/2100-1027-990503.html ("[T]he investment may also signal a shift in the alliances that span the music technology industry").

${ }^{44}$ Zomba, which is part-owned by BMG, see www.hoovers.com, has a small ownership share in MusicNet.

${ }^{45}$ Except for EMI, the smallest of the five major record companies, which licensed its music to its non-affiliated service, pressplay.

${ }^{46}$ Wall St. J., May 15, 2002.

${ }^{47}$ See John Borland, Pressplay to offer unlimited downloads, CNET News.com, July 31, 2002, available at http://news.com.com/2100-1023-947507.html?tag=fd_lede; Graham, supra.

${ }^{48}$ See Julia Angwin \& Nick Wingfield, AOL Revamps Music Service, But It s Costly, WALL ST. J., Feb. 26, 2003, at D1.
} 
By the end of 2002, however, the joint ventures had changed in important ways. First, each of the music companies agreed to license their non-affiliated joint ventures (these agreements were announced virtually simultaneously by the online ventures). Second, both of the joint ventures decreased restrictions on the number of songs that could be streamed. Third, MusicNet, as distributed through AOL, began offering burning of individual songs. ${ }^{49}$

By the end of 2002 there was also a substantial independently-owned online music service in operation, called Rhapsody, offered by Listen.com. Listen.com was founded in 1998, but its efforts to secure licenses from the five major distributors began to flower only after the labels themselves decided to move toward online distribution ventures. ${ }^{50}$ By July 2002 Rhapsody announced that it had signed agreements with all five distributors (UMG, the largest distributor, being the last to agree). ${ }^{51}$ Although initial agreements with the major distributors did not permit Rhapsody to offer burning of songs to CDs, by the end of 2002, four of the five major companies had agreed to allow Rhapsody to offer burning (Sony had not).

Online music continued to evolve in 2003. Four new independentlyowned ventures entered the market. The most significant was Apple Computer, which began an online music service ( iTunes Music Store ) offering individual songs, as well as albums, for downloading, rather than offering a monthly music subscription service (which has come to be known as the a la carte approach, as opposed to the all you can eat approach). ${ }^{52}$ It was the first service to offer downloading without a monthly subscription fee, although it was initially available only to users of Apple computers. Its attractiveness was greatly enhanced by the marketing of a complementary digital music player (the iPod) for storing and playing digital music files. After Apple s entry, and following Apple s business approach, BuyMusic.com began a service offering individual song and album downloads similar to Apple s but available on Windows PCs. ${ }^{53}$ The third new entrant was MusicNow, owned by FullAudio and primarily distributed online through Clear Channel Communications (a Phoenix, Arizona,

\footnotetext{
${ }^{49}$ See Julia Angwin and Nick Wingfield, AOL Ramps Music Service, But It s Costly, Wall ST. J., Feb. 26, 2003, at D1 (\$17.95 to burn 10 songs, more than the cost of a CD in a store; quoting 15-year old consumer complaining that the number of songs permitted is not enough ).

${ }^{50}$ John Borland, Listen.com lands last Big Five label, CNET News.com, July 1, 2002, available at http://news.com.com/2100-1023-940841.html?tag=bplst.

${ }^{51} I d$.

${ }^{52}$ See Pui-Wing Tam \& Anna Wilde Mathews, Apple Polishes Its Music Service, WALL ST. J., April 14, 2003, at B1.

${ }^{53}$ See Bob Tedeschi, Buy.com Chief Starts Site to Sell Music Downloads, N.Y. TIMES, July 23, 2003, at C4.
} 
radio broadcaster), which entered with a monthly subscription service oriented toward older adults. ${ }^{54}$ It offered streaming, tethered downloads, and burning (although, at least at the beginning, Sony had not licensed any burning from its catalogue); by the end of the year it was also offering individual songs for downloading. ${ }^{55}$ The fourth new entrant to offer individual songs was MusicMatch, which had been distributing music player software and Internet radio. ${ }^{56}$

In addition to new entry, there were two major structural changes in the online music business in 2003. RealNetworks, a minority owner of MusicNet (along with three of the five major record distributors), purchased Rhapsody, the major independent online service. ${ }^{57}$ At about the same time, Roxio, a digital media technology company which had previously acquired Napster's assets, agreed to buy substantially all of pressplay, the joint venture owned by UMG and Sony. ${ }^{58}$ Roxio s announced intention was to "build a reborn Napster service," using pressplay s infrastructure and licensing agreements and the Napster brand name, but without the peer to peer file sharing aspect. ${ }^{59}$ Although both Sony and UMG will each have a director on Roxio s board, and will be entitled to substantial income from the new Napster service, nevertheless, the sale appeared to constitute an important change in the two companies approach to online music. $^{60}$

Industry structure will likely continue to evolve in 2004. A group of music retailers (Best Buy Co., Tower Records, Hastings Entertainment Inc, Trans World Entertainment Corp., Virgin Entertainment Group Inc., and Wherehouse Music Inc.) have announced the formation of Echo Inc., a consortium to develop an online music subscription service that will let each of

\footnotetext{
${ }^{54}$ See Press Release, Feb. 17, 2003, http://www.fullaudio.com/pr.jsp?prDate=02172003.

${ }^{55}$ See http://www.fullaudio.com/partners.jsp.

${ }^{56}$ See Press Release, MusicMatch Introduces 99 Cent Downloads for the PC (Sept. 29, 2003), available

http://www.musicmatch.com/info/company/press/releases/?year=2003\&release=13.
}

${ }^{57}$ See David Bank, RealNetworks is Launching Its Own Online-Music Network, WALL ST. J., May 28 , 2003, at B7. RealNetworks chief executive, Rob Glaser, is chairman of MusicNet. See Saul Hansell, E-Music Sites Settle on Prices. It s a Start., N.Y. TIMES, March 3, 2003, at C5.

${ }^{58}$ See Don Clark \& Anna Wilde Mathews, Roxio Looks to Resurrect Napster, WALL ST. J., May 20, 2003, at B7; Nick Wingfield, Roxio Sells Shares to Revive Napster, WALL ST. J., June 30, 2003, at B5 (Roxio paid about $\$ 40$ million to acquire pressplay).

${ }^{59}$ See John Borland, Roxio taps Fanning for Napster take two, CNET News.com, February 24, 2003 available at http://news.com.com/2100-1023-985748.html). At the time, Roxio only held a license from EMI, to offer downloads and burning.

${ }^{60}$ See Clark \& Mathews, supra note 58 (pressplay was a stepping stone for finding new means to distribute music, according to CEO of Sony Music). 
the retailers distribute music on the Internet under their respective brand names. This venture, although announced in January of 2003, has yet to begin. ${ }^{61}$ WalMart has begun running a trial version of a download service, which it expects to introduce in spring 2004. ${ }^{62}$ Microsoft has announced its intention to sell downloads though its MSN Web site, using its bundled Windows Media Player. ${ }^{63}$ Sony, having sold its interest in pressplay, is planning a download service for spring 2004, along with the introduction of an inexpensive portable music player. ${ }^{64}$ Yahoo is considering entry as well. ${ }^{65}$

Although there is no publicly available information on the number of subscribers for each of the subscription services, it was reported that by early 2003 approximately 300,000 people subscribed to all the services in total (creating revenues of approximately $\$ 25$ million). ${ }^{66}$ Apple s per song service received substantial initial use, selling more than 17 million songs in its first six months. ${ }^{67}$ In terms of numbers of songs, the new Napster claims to have about 500,000 songs, MusicNet about 400,000, Rhapsody and BuyMusic about 300,000 , and Apple and MusicMatch in excess of 200,000. ${ }^{68}$

Some convergence on pricing appears to have occurred. For the monthly subscription services, there is a fee of about $\$ 10$ for access to a pool of all the

${ }^{61}$ See Nick Wingfield, Retailers Set Internet Music Venture, WALL ST. J., January 27, 2003; Penelope Patsuris, Music Chains Raise the Volume on Downloads Forbes, January 27, 2003, http://www.forbes.com/2003/01/27/cx_pp_0127music.html); www.echo.com. The current business plan includes "kiosks" inside record stores which will sell downloads or passes for downloads over the Internet.

${ }^{62}$ See John Schwartz \& John Markoff, Power Players; Big Names Are Jumping Into the Crowded Online Music Field, N.Y. TIMES, Jan. 12, 2004, p. C1.

${ }^{63}$ See Nick Wingfield \& Ethan Smith, Microsoft To Sell Music Over the Web, WALLST. J., Nov. 17, 2003, at B1.

${ }^{64}$ See Power Players, supra note 62.

${ }^{65}$ See Jim $\mathrm{Hu} \&$ John Borland, Yahoo composing music download plan, CNET News.com, Feb. 3, 2004, available at http://news.com.com/2100-1027_3-5152860.html?tag=nefd_lede.

${ }^{66}$ Angwin \& Wingfield, supra note 48 (Jupiter research estimate). See also Power Players, supra note 62 (more than 300,000 total subscribers). Rhapsody reportedly had 250,000 subscribers in late 2003, see Nick Wingfield \& Ethan Smith, With the Web Shaking Up Music, A Free-for-All in Online Songs, WaLl ST. J., Nov. 19, 2003, at A1.

${ }^{67}$ See Free-for-All, supra note 66. See also Amy Kover, It s Back. But Can the New Napster Survive?, N.Y. TIMES, Aug. 17, 2003, at p.4 (Apple sold 6.5 million songs in first three months).

${ }^{68}$ See Amy Harmon, What Price Music? How Your Favorite Song Went on 99-Cent Special, N.Y. TIMES, Oct. 12, 2003, at Section 2, Page 1. Rhapsody has more songs to listen to $(385,000)$ than to purchase $(275,000)$. 
songs on the service (allowing unlimited streaming and tethered downloads that expire when the subscription expires). The charge for downloading is approximately 99 cents a song (Apple), although at one time Rhapsody ran a promotional sale at 49 cents each, BuyMusic is charging variable amounts, and WalMart is expected to charge 88 cents; albums generally are sold for about $\$ 10{ }^{69}$ Published estimates of the royalty paid to the record companies for downloads vary from 65 to 80 cents; costs for streaming paid to the record companies are estimated to be between two-tenths of a cent and a penny for each song to which a subscriber listens (although there is a monthly guarantee for streaming of about \$5.00). ${ }^{70}$ There are also additional fees that must be paid to those who hold the rights in the musical works. ${ }^{71}$ There are still numerous variations in the rights that consumers get, in terms of numbers of downloads, burning, and sharing with other computers; these rights can vary by song as well as by Internet music service.

This is not to say that these pricing plans are the only ones possible. There is still some uncertainty about whether most consumers in the future will move completely to the online world, with no desire to maintain hard copies of music, in which case the current monthly fee might be considered to be too low. $^{72}$ Music companies (or the online services) may engage in differential pricing depending on whether a song is a hot release or part of the back catalogue. $^{73}$ Nevertheless, as Rob Glaser, the chief executive of RealNetworks, chairman of MusicNet, and (subsequently) owner of the Rhapsody online service, said in March 2003, Everyone doesn $t$ agree on everything, but everyone agrees on enough things that we can start putting products in the market.

\footnotetext{
${ }^{69}$ See, e.g., What Price Music?, supra note 68. For an earlier review of charges, see David Pogue, The Internet As Jukebox, At a Price, NY TIMES, March 6, 2003, at G1; Walter Mossberg, Rhapsody Lets You Burn CDs online at 49 Cents a Song, WALL ST. J., Feb. 13, 2003, at B1.

${ }^{70}$ See What Price Music?, supra note 68; Settle on Prices, supra note 57.

${ }^{71}$ Although there is controversy over whether buffering of music that is being streamed to a computer user is a reproduction of the musical work, thereby implicating the compulsory mechanical license, see n. 22, supra, the online ventures paid what may be a onetime royalty to the Harry Fox Agency so as to get the ventures going. See Amy Harmon, Copyright Hurdles Confront Selling of Music on the Internet, N.Y. TIMES, Sept. 23, 2002, at C1 (\$1 million up front payment by online music ventures to Harry Fox Agency, representing majority of music publishers); Interview with Nicholas Gordon, Esq., June 18, 2003.

${ }^{72}$ See Settle on Prices, supra note 57, at C5.

${ }^{73} I d$. Buy.com sells its songs at different prices; songs also have different rights of use, depending on the license from the record distributor. See Bob Tedischi, Buy.com Chief Statrts Site to Sell Music Downloads, N.Y. TIMES, July 23, 2003, at C4.

${ }^{74}$ See Settle on Prices, supra note 57, at C5.
} 
Online Music Joint Ventures: Taken For A Song

III. Antitrust Analysis of Online Music Joint Ventures

\section{A. Market Definition}

Markets are defined on the basis of substitutability by consumers and producers. That is, markets are made up of a set of products that consumers believe to be reasonably good substitutes in use and that producers of other, even of slightly different, products cannot readily make. Whether consumers or producers are likely to make substitutions can often be determined by the extent to which sellers of a set of products could raise price by a small amount and not loose so many customers, or attract so many sellers of close substitutes into producing the product, that the price rise would be unprofitable.

Prerecorded music can, of course, be listened to ( consumed ) in a variety of ways. Although the music is all the same no matter how it is listened to, each channel of distribution provides the buyer with a somewhat different product and experience. Music delivered in physical form has different characteristics than music that is broadcast over the air, although users certainly switch between the two. Similarly, music that is delivered digitally over the Internet has different characteristics than music delivered in the physical medium of a CD. And music delivered digitally over the Internet also varies by the different type of platform on which it is distributed, whether by free file-sharing services, by webcasters, and by online interactive music services.

The closest substitutes for the product sold by online music services are free file-sharing services and physical CDs. Although the streams of music that many of the online music services provide are similar to the service provided by webcasting, copyright law keeps webcasting and interactive services separate by product characteristics. Consumers who want their online music on demand can only select among various online music service offerings.

What about consumers who want to download or burn music? If the sellers of online music raised their price by some small but significant and nontransitory amount, would these consumers switch to free file-sharing services? Using the Merger Guidelines five percent test, ${ }^{75}$ that would mean a nickel increase in the price of downloaded track, based on current market prices. Although we can t say for certain what would happen, an educated guess would be that the hypothetical monopolist could make such an increase stick. Both Napster and Rhapsody have experimented with prices that were more than a nickel below 99 cents per track ( 75 cents and 49 cents, respectively) and both have raised their prices back to 99 cents without losing so many sales as to make the increase unprofitable. ${ }^{76}$ Indeed, the fact that sellers of music online can price

\footnotetext{
${ }^{75}$ See U.S. Department of Justice and Federal Trade Comm n,H ORIZONTAL MERGER GUIDELINES 1.11 (for market definition in merger cases, a 5 percent price increase lasting for the foreseeable future).

${ }^{76}$ See What Price Music, supra note 68, at p. 32. Rhapsody s sales more than tripled at
} 
their product positively without losing all their customers to zero-priced filesharing services is indication in itself that there is separate consumer demand for a legal music service, a demand which increased dramatically during 2003, despite the continued existence of free file-sharing services.

Similarly, the hypothetical monopolist of online music could raise its price by a nickel a track without losing so much business to physical CDs as to make the price rise unprofitable. For one, songs come in a bundle on a $\mathrm{CD}$, so a $\mathrm{CD}$ will not be a substitute for a consumer who wants only a particular song. For consumers who want to buy an entire album, the general online price is about $\$ 10$; an increase to $\$ 10.50$ would not likely cause consumers to switch to physical CDs, which are generally priced at around $\$ 14$.

At the same time, there is little doubt that the availability of free music has constrained the pricing of online music sellers. Presumably, the greater the difference between the price of lawfully obtained music and the zero price of infringing music, the more willing consumers will be to substitute free file sharing for priced online music (unless the industry can increase the cost of free music by increasing the enforcement risk). Indeed, the industry s willingness to continue financing litigation against consumer-infringers shows that the recording industry views undeterred infringement as a competitive threat. Similarly, it is apparent that the retail price of physical CDs constrains the pricing power of sellers of online music and that, at least for now, sellers of online music have kept their prices below the average per track price of a physical CD. $^{77}$

Paradoxically, perhaps, the argument for taking account of free file sharing is stronger in 2004 than it was in 2001 when the joint ventures were launched. The argument is stronger because in 2001 in looked as though the industry might be successful in suppressing pirated music; by mid-2003 the ability to stop file sharing services through litigation was in substantial doubt, forcing the industry to proceed against direct infringers, an easier legal case but a harder enforcement target. This is paradoxical, because the revenues from online music services were increasing substantially at the same time as the campaign to stop infringement was looking more problematic. Free file-sharing may be a continuing competitive threat, but that has not prevented priced online music from flourishing as a product for which consumers are willing to pay.

The idea that market power can exist while still being subject to some constraint is not a surprising one, of course. More than sixty years ago Learned Hand observed that Alcoa s pricing power was constrained by imports and substitute metals, but that within these constraints Alcoa still had substantial

the 49 cent price; Napster s increase in sales at 79 cents was not proportionally greater than the decrease in price. $I d$.

${ }^{77}$ See id. ( Ninety-nine cents is only slightly less than the cost of a song on a CD [given the usual price, around $\$ 14$, and the usual number of tracks, around 12]. ). 
power over price. $^{78}$ More recently, Microsoft s monopoly power in the operating systems market was somewhat constrained by competition from pirated software, but that was hardly reason to ignore the substantial power that it could and did exercise even subject to that constraint. ${ }^{79}$

\section{B. Competitive Effects of Joint Ventures}

Joint ventures, like any other form of integration, offer efficiency benefits and pose competitive risks. Joint ventures allow firms to pool capital and spread risk. They may permit firms to achieve economies of scale or scope which reduce the cost of the product, or to bring products to market more quickly, or to combine different capabilities in a way that none of the individual firms would be able to do. ${ }^{80}$ Joint ventures involving intellectual property can provide additional benefits. Intellectual property rights can be fragmented and conflicting. Making effective use of these rights often requires some degree of joint effort (pooling) so that rights can be combined in a way that will allow a product to be produced and will clear conflicting claims. Although the need for pools and collective action has long been acknowledged for patent rights, copyrights can be subject to the same problems, as, indeed, the splintering of rights in the music industry demonstrates. ${ }^{81}$

Joint ventures also have their anticompetitive risks. The primary structural risk comes from the fact that joint ventures often combine the efforts of actual or potential competitors. To the extent that the co-venturers might have produced the product individually, or one venturer might have produced the product while the other remained as a potential entrant, a joint venture ends competition between the co-venturers with regard to the output of the joint venture. ${ }^{82}$ Joint ventures, by functioning as joint sales agencies, might allow the venturers to end interseller price competition and agree on price. ${ }^{83}$ Joint

${ }^{78}$ See United States v. Aluminum Co. of America, 148 F.2d 416 (2d Cir. 1945).

${ }^{79}$ See United States v. Microsoft Corp., 84 F. Supp. 2d 9, 25 (D.D.C. 1999) ( 58), vacated and remanded on other grounds, 253 F.3d 34, cert. denied, 534 U.S. 952 (2001).

${ }^{80}$ See Federal Trade Comm $\mathrm{n}$ and U.S. Department of Justice, ANTITRUST GUIDELINES FOR COLlaborations AMONG COMPETITORS 2.1.

${ }^{81}$ See Robert P. Merges, Contracting into Liability Rules: Intellectual Property Rights and Collective Rights Organizations, 84 CALIF. L. REV. 1293 (1996); Amy Harmon, Copyright Hurdles Confront Selling of Music on the Internet, N.Y. TIMES, Sept. 23, 2002, at C1 (describing multiplicity of rights that need to be cleared to provide online music service).

${ }^{82}$ See, e.g., United States v. Penn-Olin Chemical Co., 378 U.S. 1710 (1964) (joint venture may have eliminated potential competition from one of the co-venturers remaining on the fringe of the market and threatening entry).

${ }^{83}$ See, e.g., Appalachian Coals, Inc. v. United States, 288 U.S. 344 (1933) (joint sales agency for marketing coal; subject to rule of reason); United States v. Columbia Pictures Indus., 
ventures might also pose risks to competition at different levels of the production or distribution process. The co-venturers might withhold important inputs from competitors, or find other ways to raise their rivals costs. The co-venturers might also use the joint venture to exchange information in ways that affect price in the markets in which the co-venturers continue to compete.

\section{Forming the Joint Ventures}

\section{BMI s guidance}

The case that would seem most directly on point with regard to the formation of the online music joint ventures is the Supreme Court $\mathrm{s}$ decision in Broadcast Music, Inc. v. Columbia Broadcasting System, Inc. ${ }^{84}$ That case involved the licensing practices of ASCAP and BMI, the two major organizations in the United States that license performance rights to musical works. ASCAP and BMI offered only a blanket license to all the music in their repertories; neither offered licenses for the performance of individual musical works. The Supreme Court held that ASCAP and BMI s joint licensing of performing rights was subject to a rule of reason analysis under Section 1 of the Sherman Act. Even though the blanket license substantially reduced interseller price competition with regard to licensing fees for individual music compositions, and could have been literally viewed as price fixing, the Court required a fuller competitive analysis. Central to its decision was the recognition of the integrative efficiency benefits of the joint operation. The blanket license is a different product ... of which the individual compositions are the raw material. ASCAP and BMI made a market in which individual copyright owners are inherently unable to fully effectively compete.

Thus $B M I$ is both legally and factually relevant to an analysis of the online music joint ventures. Legally, $B M I$ underscores the importance of considering the efficiency benefits of competitor collaborations, stressing the need to allow for joint efforts among competitors where the joint effort is necessary to produce the product (in that case, no individual copyright holder could offer a blanket license). Factually, BMI and ASCAP shed light on the need for copyright holders to pool the rights granted by the copyright laws in a way that economizes on what would otherwise be the high transactions costs of numerous low-value licenses between individual users and the copyright owners.

Inc., 507 F. Supp. 412 (S.D.N.Y. 1980) (joint venture of four motion picture companies to provide new pay television service; subject to per se rule), aff $d, 1981$ U.S. App. LEXIS 21309 (2d Cir. 1981).

\footnotetext{
${ }^{84} 441$ U.S. 1 (1979).

${ }^{85} I d$. at $22-23$.
} 
$B M I$ is generally assumed to be a critical case for justifying collaborative behavior among competitors, with particular relevance to intellectual property rights. What can easily be overlooked, however, is that $B M I$ might have some very different lessons to teach, once greater attention is paid to institutional detail both for performing rights organizations and for online music joint ventures. In fact, the development of online music may show that $B M I$ itself is now wrong.

2. Fragmented rights and the need for pooling

ASCAP s formation dates back to a meeting in 1910 between Giacomo Puccini and his U.S. publisher, at which Puccini mentioned the role played by the Italian performing rights society in securing royalties for composers (the performance right only entered U.S. law in 1897). ${ }^{86}$ ASCAP was founded four years later. Its commercial and legal history since that time demonstrates a continuing effort by the music industry to capture revenues from each newlyemerging entertainment medium, from radio, to television, to motion pictures, to cable television, and now to the Internet. ${ }^{87}$ The justifications for collective action in pursuing these revenues, however, as set out fifty years ago by Sigmund Timberg, the Justice Department lawyer responsible for the consent decree against ASCAP, have remained constant. ${ }^{88}$ First is the pragmatic plea of commercial necessity which arises from the need of music users to obtain the right to perform the music in a sure and speedy way. Second is the need of a user to be assured that it has permission to perform the copyrighted work and will not be subject to conflicting claims of infringement. Third is the helplessness of its individual members to enforce their rights, either because of the difficulty of detection or the high cost of litigation relative to the value of any single infringement.

Although each of these justifications involves transactions costs efficiencies, they do not necessarily justify the pooling and joint licensing of all performing rights in a single organization. For one, there is no reason why the need for collective enforcement of performance rights also means that these rights must be collectively licensed. Presumably, copyright holders could contract with a central agency to perform the policing function alone; this would capture the economies that flow from a single agent enforcing the rights of many

\footnotetext{
${ }^{86}$ See Bernard Korman and I. Fred Koenigsberg, Performing Rights in Music and Performing Rights Societies, J.COPYRIGHT SOC. OF THE U.S.A. 332, 350 (1986).

${ }^{87}$ See id. at 337-342. The consent decree, originally entered in 1941, was amended in 2001 to cover on line music users that publicly perform works via the Internet. See United States v. ASCAP, 2001-2 Trade Cas. (CCH) 73,474 ( II (H) (second amended final judgment).

${ }^{88}$ See Sigmund Timberg, The Antitrust Aspects of Merchandizing Modern Music: The ASCAP Consent Judgment of 1950, 19 L.\& CONTEMP. PROBS. 294, 297-98 (1954).
} 
holders more efficiently than each individual rights holder could. ${ }^{89}$ In fact, the recording industry itself shows that the efficiency of joint enforcement of sound recording rights need not be connected to the pooling of rights. The industry $\mathrm{s}$ copyright infringement litigation against piracy has been led by a trade association vehicle, the Recording Industry Association of America, which does not engage in licensing. ${ }^{90}$

For another, the efficiency of collective licensing is related to the magnitude of the collective action faced by copyright holders and users. Performing rights ownership is highly fragmented. At the time the ASCAP decree was amended in 1950 there were 365 music publishers and 2,040 participating composers and authors. ${ }^{91}$ By contrast, approximately 80 percent of the sound recording rights critical for an online music venture are controlled by five companies.

Nor is it clear why the efficiency of using a collective agency to license rights necessarily requires that agency to offer these rights only on a pooled basis. Users may want to know where to go for copyright permissions, but that does not mean that they necessarily want to license all the rights that the collective has to offer. Put otherwise, ASCAP s refusal to offer a per-song license makes the collective arrangement less efficient than it should be. Consumer welfare would be enhanced if the collective provided both the economies of offering the rights of numerous holders in one spot while still providing the licensee the ability to choose the rights that the licensee prefers. This was the choice that CBS wanted in BMI, of course.

In $B M I$ the Court noted the ability of CBS to negotiate per song royalties directly with the copyright holder, but took this as proof of the efficiency of a blanket license rather than as an indication that efficiency could be enhanced if ASCAP were to offer both a blanket license and a per song license. ${ }^{92}$ The Court s unwillingness to recognize the welfare loss from ASCAP $s$ refusal to provide individual licenses may perhaps have been the result of its implicit assumption that performing rights societies could not easily operate in any way other than by a blanket license. As Sigmund Timberg wrote in 1954: A blanket license covering ASCAP s total repertory is the price of avoiding industrial palsy in the entertainment world, says ASCAP, and thus far no important

\footnotetext{
${ }^{89}$ See Stanley M. Besen, Sheila N. Kirby, \& Steven C. Salop, An Economic Analysis of Copyright Collectives, 78 VA. L. REV. 383, 390 (1992) ( A premise of our analysis is that significant economies result from collective administration. ).

${ }^{90}$ See http://www.riaa.com/about/default.asp ( RIAA members create, manufacture and/or distribute approximately $90 \%$ of all legitimate sound recordings produced and sold in the United States )

${ }^{91}$ See Timberg, supra note 88 , at 313.

${ }^{92}$ See 441 U.S. at 21 and n. 35.
} 
commercial user of ASCAP s music has contradicted this assertion for any length of time.

Whatever the strength of this assumption when BMI was decided, the efficiency which justified the refusal to offer individual licenses likely no longer holds. In fact, the online music joint ventures help prove the point. Online music ventures began by only offering a blanket license, that is, legal access to an entire pool of music for a single fee (the all you can eat model). Competition from free file sharing services showed, however, that consumers had a strong preference for consumption per-song; indeed, consumers were rejecting even the smaller technological bundle of the album in favor of individual choices. Competition then forced the online ventures to recognize this demand and offer sales of individual songs in addition to a monthly subscription to the entire repertory of songs that the service wanted to offer. Apple was the first to recognize this consumer demand; all the others followed when it became apparent how strong that demand was.

Returning to the Court s decision in $B M I$, by allowing copyright holders to agree collectively not to offer single-use licenses, when such an offering would have increased consumer welfare, the Court may actually have retarded the development of competition on the price of performing rights licenses. In fact, whatever problems the performing rights organizations might have faced in the past in licensing individual compositions at competing prices, those technological problems have been reduced (if not eliminated) by the Internet itself and the development of distribution platforms which make such individual transactions economically feasible. Other copyright collectives, making use of the Internet, already offer both per-use and blanket licenses, with per use royalties set by individual copyright holders. ${ }^{94}$ Thus $B M I$, it turns out, is not as strong a case for collective action as is generally thought. ${ }^{95}$ Far from offering

${ }^{93}$ Timberg, supra note 88 , at 297.

${ }^{94}$ The Copyright Clearance Center licenses text reproduction and distribution rights on a per-use basis, with royalties set by copyright holders; it also offers a blanket license. See https://www.copyright.com/Help/HelpApsFAQ.asp\#5 (copyright holders set their own royalty fees; clearance center charges a uniform processing fee). Its willingness to offer these choices may be explained by the fact that, as in the music industry, holders of copyrights in written works face the difficult task in getting consumers to pay when piracy is cheap and easy.

\footnotetext{
${ }^{95}$ The Department of Justice may be ready to question the continued vitality of $B M I$ with regard to the refusal to offer per-song licenses. See Memorandum of the United States in Support of the Joint Motion to Enter Second Amended Final Judgment, United States v. ASCAP, at 9 (S.D.N.Y., Sept. 4, 2000) ( Technologies that allow rights holders and music users to easily and inexpensively monitor and track music usage are evolving rapidly. Eventually, as it becomes less and less costly to identify and report performances of compositions and to obtain licenses for individual works or collections of works, these technologies may erode many of the justifications for collective licensing of performance rights by PROs. The Department is continuing to investigate the extent to which the growth of these technologies warrants additional changes to the antitrust decrees against ASCAP and BMI, including the possibility that the PROs should be prohibited from collectively licensing certain types of users or performances. ), available at http://www.usdoj.gov/atr/cases/f6300/6395.htm.
} 
strong justification for collective action by the record companies, $B M I$ actually shrinks down to its underlying analytical approach: antitrust analysis must pay careful attention to the asserted efficiencies to see whether they are worth the cost of reduced competition.

\section{Demand side economies and one-stop shopping}

A major justification for the music joint ventures, at least at their inception, was thought to be consumer desire for one-stop shopping. An online music service could be that hoped-for celestial jukebox, providing in one place all the music that exists in the world. This was thought possible on the supply side, perhaps because Internet distribution (in contrast to distribution in physical space) appeared to provide infinite economies of scale. This was thought desirable on the demand side because it would economize on consumer search costs. Similar claims have been made for other Internet producer joint ventures, such as Orbitz. As difficult as it may be to believe now, the claim for the efficiency of a single music site was a serious one in 2001.

Recall that one of the justifications for a performing rights organization is the need for users to gain rapid and indemnified access to copyrighted works, with assurance that they would not be subject to conflicting claims of infringement. ${ }^{96}$ What better than a single source for licensing to achieve these aims?

Once again, however, the BMI case helps us see how weak this efficiency rationale actually is. One of the curious anomalies in the market for licensing performing rights is that there are three performing rights organizations in the United States, not just one. ${ }^{97}$ ASCAP is the leading organization. BMI, the second largest organization, was formed in 1940 by broadcasters as a response to ASCAP s effort in 1939 to license broadcast networks for the first time, as well as ASCAP s simultaneous effort to raise its license fees for broadcast stations. ${ }^{98}$ In 1941 the broadcasters boycotted ASCAP music and began broadcasting mostly Latin music. By late 1941 new licensing arrangements were agreed to between the broadcasters and ASCAP, a peace of sorts. ${ }^{99}$ BMI continued in operation, however, perhaps in an effort by the broadcasters to maintain some leverage over ASCAP in negotiating royalties. ${ }^{100}$ Although BMI has historically

${ }^{96}$ See BMI, 441 U.S. at 20.

${ }^{97}$ This is unlike the situation in other countries where there is only one performing rights organization. For a description of foreign performing rights societies, see Richard Schulenberg, LEGAL ASPECTS OF THE MUSIC INDUSTRY (1999).

${ }^{98}$ At the time, ASCAP was estimated to control between 85 and 90 percent of the music required by users such as broadcasters and dance halls. See Buck v. Swanson, 33 F Supp 377 , 386 (D. Nebr 1939).

${ }^{99}$ Korman \& Koenigsberg, supra note 86 , at 351 n. 87.

${ }^{100}$ See Besen, Kirby, \& Salop, supra note 89 , at 402 (discussing the entry of BMI). 
had lower revenues than ASCAP and fewer songs in its repertory, its compositions now comprise about the same percentage of music performed in most venues as does ASCAP s. ${ }^{101}$

One particularly interesting point about the existence of the three separate performing rights organizations is that their repertories are mutually exclusive. Songs can be licensed only to one association at a time, and composers and publishers cannot belong to ASCAP and BMI at the same time. This means that users of music must take licenses from each of the organizations if they really want the unplanned, rapid and indemnified access to any and all of the repertory of compositions, as the Court in BMI thought they would, unless they are willing (and able) to be more selective in the music that they perform.

The willingness of users to establish a competing performing rights organization, and the willingness of users to take licenses from more than one organization, indicates that the efficiencies from one-stop shopping may be small enough to be outweighed by the benefits that can flow from competition among different licensors of performing rights. Put otherwise, although some degree of collective action may be efficient, this does not tell us what the optimal size of the collective might be.

For online music joint ventures, the benefits of one-stop shopping are even weaker than they are for performing rights organizations. It is surely cheaper for a user to click to another site on the Internet for the music that he or she seeks than it is for a licensee of performing rights to deal with three performing rights organizations. Switching costs would be low even were the online music companies offering only a blanket license to an entire repertory (consumers might subscribe to two services, or switch at the end of a month $\mathrm{s}$ subscription). But switching costs are particularly low where consumers seek and can get individual songs; searching for a specific song on several websites does not seem like a particularly arduous task.

The other side of the equation is that multiple ventures offer the possibility of competition. This turns out to be true even in the performing rights organization context, where licensing fees negotiated with one organization can have an impact on the licensing fees of another. ${ }^{102}$ The short history of online music shows that it is much more the case for online music ventures. Rather than a single platform, marketplace competition has produced a diversity of

${ }^{101}$ See Memorandum of the United States in Support of the Joint Motion to Enter Second Amended Final Judgment, supra note 95, at 6-7 (ASCAP has over 8 million songs in its repertory; BMI has 4 to 5 million). SESAC, the third performing rights organization, was founded in 1930; its repertory, once limited to European and gospel music, has diversified to include today's most popular music, including dance hits, rock classics, the best of Latina music, the hottest jazz, the hippest country and the coolest contemporary Christian music. See http: //www.sesac.com/aboutsesac/aboutmain.asp.

${ }^{102}$ See ASCAP v. Showtime/The Movie Channel, Inc., 912 F.2d 563, 594 (2d Cir. 1990) (ASCAP rate court proceeding; using fees negotiated with BMI as benchmark for fees for ASCAP), discussed, Besen, Kirby, \& Salop, supra note 89, at 405-407. 
efforts to market online music, providing different services and different packages for selling online music. If we now had only a single platform, or the two industry joint ventures that we began with in 2001, consumers would never have received the benefits of this competition.

\section{Applying $B M I$}

The formation of pressplay and MusicNet in 2001 meant that the coventurers in each of the ventures would not compete against each other by selling online music services. On a basic level this competition might have taken the form of the individual music companies selling music online at different prices (whether price were set for the entire repertory or on a per song basis). On a more important level, the competition might have taken the form of greater platform innovation, for example, offering music combined with different informational services, or offering music with different rights (e.g., full downloads). ${ }^{103}$ These possibilities were apparent even in 2001, when the ventures were formed.

The joint ventures, of course, were still free to compete against each other (although, like the performing rights societies, they did so initially with mutually exclusive repertories), so price competition was not extinguished. Further, the venturers were still free to license their music to other online music ventures, again much as the copyright holders in ASCAP and BMI, although it took a full year before all the music companies licensed any competitor outside the ventures.

$B M I$ teaches us not to condemn collaborative arrangements on their face for literal price (or product) fixing. Even though each of the co-venturers could have produced the new product on its own (getting licenses from other companies for music they didn t control), and even though there are no demand side efficiencies from offering a single site (or two sites), there was also one obvious procompetitive effect from the joint ventures. Output in the online music market was expanded by the entry of the two ventures.

How to balance the prediction of competitive harm from the restriction of competition among the co-venturers against the reality of new entry? First there might be little to worry about if the two ventures themselves were not likely to have market power; in that case independent entry would not much matter. Assessing the ventures market power would have been a somewhat difficult exercise in 2001, of course, given the unformed nature of the online music market when the ventures started, as well as the existence of competition from free file sharing services which provided at least some constraint on the ventures price and product decisions. Nevertheless, there is one structural factor that would have led to a prediction that the ventures would have market

${ }^{103}$ See COMPETITOR COLLABORATIONS GUIDELINES, 2.2 (potential harm to competition from increasing price or reducing quality of innovation below what likely would prevail in the absence of the agreement). 
power. Each venture brought together companies that controlled approximately 40 percent of the prerecorded music market; licenses to use this music are essential to an online music venture, in the sense that, for a lawful online music venture, there are no available substitutes. Using market shares of these inputs as a proxy for market shares in online distribution, the market would have looked very concentrated indeed. ${ }^{104}$

The joint venturers were, however, contractually free to license rivals in the online music market, thereby creating competition on price and product quality and diminishing their market power. But why would they do such a thing? All their incentives would have been not to license, or, at best, to license strategically, so as to disadvantage competitors. Firms in control of essential inputs do not usually want to help create competitors. Indeed, given the concentrated nature of the prerecorded music industry, the transparency of information in the industry, the extensive contacts that industry participants have with one other, and the economic interest each participant had in not cannibalizing physical CD sales, overt agreements not to license competing online music ventures would hardly have been necessary. ${ }^{105}$ The prediction of tacit collusion regarding refusals to license other ventures, plus the prediction of less than vigorous competition in a two-firm online music market, would have led to the conclusion that anticompetitive effects from these joint ventures would be likely.

And yet, the record companies did license their music to others. Does that tell us that predictions of anticompetitive effects when the ventures were formed would have been misguided and that the contractually unrestrained ability to license meant that the creation of these joint ventures was not a competition problem? The answer to both parts of this question should be no. The post-formation licensing behavior of the record companies has been the product of incentives, but of a particular sort. The initial willingness to license Rhapsody came slowly and grudgingly, for example, likely motivated more by a concern for antitrust liability than by some desire to see competitors flourish, coming, as it did, at the same time that the Department of Justice was investigating the ventures and as a federal judge had expressed concern in open court about whether the ventures would pass antitrust muster. ${ }^{106}$ More

\footnotetext{
${ }^{104}$ This would, at least, place the ventures outside either of the Guidelines safety zones. See id. at 4.2 (twenty percent of the relevant market), 4.3 ( three independently controlled ventures for research ventures that require specialized assets to engage in competitive research).

${ }^{105}$ The Department of Justice did consider in its investigation whether the major record labels used their joint ventures to suppress the growth of the Internet as a means of promoting and distributing music, in order to protect their present positions in the distribution of music on physical media, such as CDs, but found that this fear did not materialize given the subsequent licensing of music by the venture participants. See Department of Justice, Closing Statement, supra note 1 , at $3-4$.

${ }^{106}$ See In re Napster Inc. Copyright Litig., 191 F.Supp.2d 1087, 1108-09 (N.D. Cal., 2002) (joint ventures look bad, sound bad and smell bad ). Similarly, the lack of a contractual restriction on licensing could very well have been the product of careful antitrust counseling, given the importance of non-exclusive licenses in BMI. See also United States v. Columbia
} 
importantly, subsequent licensing may be explained by marketplace incentives arising from the industry $\mathrm{s}$ inability to end consumer record piracy. To the industry s dismay, it still faces competition from file sharing. In that environment, exclusion of competitors by controlling the essential inputs is not possible. A better business strategy, then, is to follow the one that applies in physical space, that is, sell to everyone. ${ }^{107}$ It is no wonder that the owners of pressplay decided to sell pressplay to RealNetworks, a firm that can more effectively distribute digital music than pressplay could. As the CEO of Sony Music was quoted as saying: We want to be part of this space [digital music distribution], but we don t feel that we, on a stand-alone basis, need to dominate one platform.

Prediction of anticompetitive effect is only one half of $B M I$. There is still the fact that the joint ventures added new entrants to a nascent market, providing consumers with choices that had not been in the marketplace. Would forbidding these joint ventures have meant less competition (lower output) than there would be if the ventures were allowed to enter and compete, albeit imperfectly? Potential competition analysis might answer this question, depending on what the plans were of any of these firms to enter independently, or to threaten independent entry. ${ }^{109}$ But even if none of the record companies would have independently entered, this does not mean that we would have been worse off without the joint ventures. One important economic aspect of intellectual property is that, unlike physical property, its use by one party does not preclude simultaneous use by another. Without the joint ventures there would have been no incentive to deny use of these intellectual property rights to all other entrants. Even if the industry had succeeded in stopping file sharing services and widespread consumer infringement, the huge demand for digital music that these file sharing services uncovered would have led the industry to try to sell its music over the Internet one way or another. Whether digital music would have been provided by licensing independent firms, or through vertical integration by individual record companies, this demand would not have long gone unsatisfied.

Pictures Indus., Inc., 507 F. Supp. 412 (S.D.N.Y. 1980) (granting to the joint venture 9-month exclusive license of motion pictures, by motion picture co-venturers that controlled one-half of the essential product of the industry, held to be per se unlawful group boycott), aff $d, 1981$ U.S. App. LEXIS 21309 (2d Cir. 1981)

${ }^{107}$ See Wingfield and Smith, Free-for-All, supra note 66, at A1 ( For years, the major record labels balked at licensing their song catalogs to legitimate music sites, and most of them burdened the music with unwieldy technical safeguards that prevented consumers from recording songs onto CDs or transferring them to portable music players. Now, the labels have gone headlong in the other direction. ).

${ }^{108}$ Clark \& Matthews, supra note 58.

${ }^{109}$ For example, Sony subsequently announced its intention to enter independently. See Power Players, supra note 62, at C3. 


\section{Remedy}

Suppose that the analysis of the formation of the joint ventures is correct in its assessment that the predicted anticompetitive effects outweighed the procompetitive justifications, what remedy would have been appropriate? The most obvious remedy, of course, would have been to enjoin the ventures from starting operations; or, subsequently, requiring the venturers to divest their ownership interests, leading, perhaps to the unwinding of the ventures. The coventurers would then have been free to enter individually or to acquire sole control of one of the ventures. The injunctive provisions could have been limited to allow joint entry if market conditions changed sufficiently so that joint entry would no longer be anticompetitive.

An alternative to unwinding the venture might have been some form of non-discriminatory licensing under which the record companies would have been required to license other online music ventures on terms no less favorable than the terms under which they licensed their own joint ventures. Although this seems less drastic than divestiture, regulation of licensing might have ended up being more difficult to carry out and may have had unintended consequences on competition. ${ }^{110}$ Even in a compulsory licensing regime the record companies incentives would have been weak to license other ventures on terms that would be more favorable than the terms under which they license their own ventures. This might have meant that a compulsory license requirement would have ended up homogenizing those offerings, a particularly unwanted outcome for a product in its early stages of development. Further, compulsory licensing often leads to further review of the terms of particular contracts. The incentives would be great for the joint venture participants to structure their agreements in a way that would disadvantage competitors (for example, by requiring the joint venture to pay high royalties), or might simply prove unattractive to competitors (for example, by placing restrictions on burning). Review of such terms, however, would likely be a difficult process, as it has been for other compulsory licenses of copyrighted music. ${ }^{111}$

Here again, our experience with ASCAP and BMI should give us pause about the costs and benefits of such a decree. The ASCAP consent decree, entered in the original litigation in 1941, has been a continuing source of controversy. In recent years, the federal district court responsible for overseeing the decree has been required to decide on reasonable fees under the terms of

${ }^{110}$ Compare Jeffrey L. Harrison, Online Music: Antitrust and Copyright Perspectives, 47 ANTITRUST BULL. 465, 488-89 (2002) (nondiscriminatory license requirement would be effective response, although there are complications from such a requirement) with Fagin et al., supra, at 522-27 (rejecting compulsory licensing as least plausible solution).

${ }^{111}$ See Library of Congress, Copyright Office, Determination of Reasonable Rates and Terms for the Digital Performance of Sound Recordings and Ephemeral Recordings, 67 Fed. Reg. 45,240 (July 8, 2002) (reviewing report of the Copyright Arbitration Royalty Panel on rates and terms under the statutory compulsory license for webcasting; process began in 1998). 
the decree, and the court, the parties, and the Department of Justice have been required to continuously review the decree to keep it up to date. ${ }^{112}$

\section{Conclusion}

This article has argued that the appropriate analysis of the online music joint ventures, when announced in 2001, would have been to find that they were unreasonable restraints of trade in violation of Section 1 of the Sherman Act. This conclusion should have held even under the rule of reason inquiry mandated by $B M I$.

The joint ventures were made up of record companies that controlled approximately 80 percent of the non-substitutable inputs for a lawful online music service (that is, the licenses to the necessary sound recordings). This made it predictable that the ventures would diminish platform and price competition in the online music market, whether in the form of competition between the ventures or, more importantly, in the form of the competition that would likely have emerged if the record companies did not start joint ventures but instead licensed their music freely to independently owned online music providers. Although this predicted anticompetitive effect relies heavily on an ex ante view of the venturers licensing incentives both with and without joint venture entry, particularly their incentives to license strategically, these anticompetitive effects still outweigh the very slight efficiency benefits from the joint ventures. As a closer comparison with the performing rights organizations involved in $B M I$ shows, collective action in the online music industry was not necessary to produce an online music service and offered only the barest of demand-side benefits in the form of modest one-stop shopping. The appropriate remedy would have been to enjoin the operation of pressplay and MusicNet, requiring either divestiture or unwinding of the ventures.

As we know, however, the online market has not turned out as predicted. The record company owners of pressplay have divested their interests. Licensing appears to be fairly open (although it is unclear what restrictions are being placed on various licensees) and there is a proliferation of offerings.

${ }^{112}$ The Department of Justice, for example, has complained about the extent to which the per-program and per-segment licenses required under the consent decree have a real possibility of constraining ASCAP s market power by allowing users to substitute some of their music licensing needs away from ASCAP. See Memorandum of the United States in Support of the Joint Motion to Enter Second Amended Final Judgment, supra note 95, at 32 n.32. Section IX of the decree requires ASCAP to license at a reasonable fee. See United States v. ASCAP, 20012 Trade Cas. (CCH) 73,474 (S.D.N.Y.) (second amended final judgment); this has sometimes required formal judicial findings. See, e.g., United States v. ASCAP, 1999 U.S. Dist. LEXIS 7778 (S.D.N.Y. 1999) (local cable system operators). Korman and Koenigsberg, supra note 86 at $356 \mathrm{n} .123$, write that as of 1985 there had been no formal trial proceedings over the decree $\mathrm{s}$ requirement that fees be reasonable, although users had employed court proceedings as a context for negotiations ... often with the aid of the court. 
However one might compute market shares at the moment, it would be doubtful that the market share held by MusicNet (the remaining joint venture) comes close to reflecting the shares its owners have in the wholesale market for prerecorded music. Ironically, time and the owners of the ventures have done the work of antitrust remedies, producing divestiture of ownership of one joint venture and full access to the essential inputs controlled by the co-venturers.

To what do we owe our good fortune? Surely it is to the inability of the music industry to control the widespread infringement of their copyrights. Whatever one thinks about the breadth of intellectual property rights today, ${ }^{113}$ or about the extent to which such infringement adversely affects the incentives of those in the industry to create and distribute new music, one must acknowledge that the competition posed by unstoppable infringement changed the record companies incentives with regard to providing digital music on the Internet. The antitrust analysis of the joint ventures was based on the assumption that the venturers controlled the essential inputs. When it became clear to them that they did not, they moved to a more efficient and more competitive strategy. The result has been the development of online music joint ventures and the increasing variety in the platforms on which this music is being distributed.

It may be that the wait-and-see approach to enforcement that the Justice Department followed was institutionally appropriate. This is an industry that is still in flux, based as it is on technologies that are still evolving, both in terms of the software platforms for delivering digital music and the hardware that now is being employed to store and transport digital music files. Still, there is no reason to believe that we have reached an equilibrium where we can comfortably leave online music to the dictates of marketplace competition, either. It is not likely that all the current sellers of online music will find the market profitable and it is still unclear what the optimal business model for delivering digital music over the Internet will be. ${ }^{114}$ What is clear is that there is an underlying competition problem if control of the essential inputs returns to the hands of a concentrated production industry, and one which may become even more concentrated in the future.

The incentives to control distribution over the Internet remain. Care should be taken in the event that the markets shift once again and provide the industry the ability to control the distribution of those inputs. We could yet be taken for a song.

\footnotetext{
${ }^{113}$ See generally EXPANDING THE BOUNDARIES OF INTELLECTUAL PROPERTY: INNOVATION POLICY FOR THE KNOWLEDGE SOCIETY (Rochelle Dreyfuss, Diane Zimmerman, \& Harry First, eds. 2001).

${ }^{114}$ See Wingfield \& Smith, Free-for-All, supra note 66, at A1 (predicting that only three to six companies will be operating in the online music market by 2005).
} 